DOI:

Вікторія Прилипко, кандидат педагогічних наук, викладач кафедри фундаментальних $і$ галузевих юридичних наук, факультет права, гуманітарних і соціальних наук,

Кременчуцького національного університету імені Михайла Остроградського

\title{
ВИКОРИСТАННЯ ЕЛЕКТРОННОЇ НАВЧАЛЬНОЇ ПЛАТФОРМИ МООDLЕ ЯК ЕФЕКТИВНИЙ СПОСІБ ФОРМУВАННЯ ПРАВОВОЇ КОМПЕТЕНТНОСТІ БАКАЛАВРІВ ІНЖЕНЕРНИХ СПЕЦІАЛЬНОСТЕЙ У ПРОЦЕСІ ФАХОВОЇ ПІДГОТОВКИ
}

Статтю присвячено висвітленню досвіду роботи з інформачійними комп'ютерними технологіями в освітньому прочесі, які стають обов'язковим елементом системи професійної підготовки майбутніх фахівиів у закладах вищої освіти України та спрямовані на підвищення ефективності означеного процесу. У дослідженні акиентовано увагу на оптимізачії навчальної взаємодії між викладачами та студентами за допомогою віртуальної електронної навчальної системи Мооде. Проаналізовано вітчизняний й закордонний досвід розробки окресленої проблеми. Зроблено узагальнення, щзо застосування дистанційної платформи Moоdle у проиесі фахової підготовки бакалаврів інженерних спеціальностей під час опанування правових дисииплін підвищуватиме мотивацію студентів, забезпечуватиме різноманітність й оригінальність презентації матеріалу, сприятиме розвитку навичок самостійної та пошукової роботи студентів, а також їхніх творчих здібностей.

Ключові слова: правова компетентність; інформаційні комп ютерні технології; електронна платформа Mоодlе; бакалаври інженерних спеиіальностей; професійна підготовка.

תim. 7.

Viktoriia Prylypko, Ph.D.(Pedagogy), Lecturer of the Fundamental and Branch Legal Sciences Department Faculty of Law, Humanity and Social Sciences, Kremenchuk Mykhailo Ostrohradskyi National University

\section{USE OF ELECTRONIC EDUCATIONAL PLATFORM MOODLE AS AN EFFECTIVE METHOD OF FORMATION OF LEGAL COMPETENCE OF BACHELORS OF ENGINEERING SPECIALISTS IN THE PROCESS OF PROFESSIONAL TRAINING}

The article is devoted to the experience of working with information computer technologies in the educational process as a mandatory element of the system of professional training of future professionals in higher education institutions of Ukraine and aimed at improving the efficiency of this process. The research focuses on optimizing the learning interaction between teachers and students by using the virtual e-learning system Moodle. The specific features of the educational system are highlighted, the structural elements, tools, functionalities are determined. The attention is devoted to the use of this platform in the process of the professional training of bachelors of engineering specialties, during the formation of legal competence in the process of professional training. National and foreign experience in developing the outlined problem is analyzed.

The concept of legal competence of the bachelor of engineering specialties is defined. It is emphasized that the competitiveness of a modern specialist depends on the formation of his professional competence. It contains a number of components in its structure, including legal competence. It was found that the process of acquiring legal competence in bachelors of engineering is based on the formation of three components: cognitive, emotional and volitional and activity.

The requirements of educational standards for the training of engineering specialists regarding their mastery of the components of legal competence are studied. The ways of realization of the process of formation of legal competence of future engineers with the help of the Moodle training platform are revealed. It is generalized that the use of the Moodle remote platform in the process of professional training of bachelors of engineering in mastering legal disciplines will increase the students' motivation, provide variety and originality of material presentation, and promote the students' skills of independent and educational work and their creative abilities.

Keywords: legal competence; computer information technologies; Moodle e-learning platform; bachelors of engineering specialties; professional training. 


\section{ВИКОРИСТАННЯ ЕЛЕКТРОННОЇ НАВЧАЛЬНОЇ ПЛАТФОРМИМООDLЕ ЯК ЕФЕКТИВНИЙ СПОСІБ ФОРМУВАННЯ ПРАВОВОЇ КОМПЕТЕНТНОСТІ БАКАЛАВРІВ ІНЖЕНЕРНИХ СПЕЦАЛЬНОСТЕЙ У ПРОЦЕСІ ФАХОВОӤ ПДГОТОВКИ}

освіти України, переорієнтація на провідні європейські тенденції свідчить про те, що використання потенціалу електронних ресурсів в освітньому процесі сьогодні вже є невід'ємною складовою процесу професійної підготовки в ЗВО фахівців будь-якого профілю, тим більше інженерного.

Організація навчального процесу за допомогою використання інформаційних технологій суттєво збільшує зацікавленість дисципліною, стимулює процес вивчення і засвоєння, розширює перелік методичних прийомів та технік. Численні інтерактивні інструменти, платформи дистанційного навчання зокрема, відкривають перед викладачем широкий спектр можливостей для реалізації компетентнісного підходу та забезпечують комплексний всебічний розвиток особистості студента.

Необхідно також акцентувати увагу на тому, що конкурентоспроможність випускника закладу вищої освіти визначається сформованістю низки компетентностей, які дозволятимуть якісно здійснювати професійну діяльність. Принцип конкурентоспроможності майбутніх фахівців в удосконаленні якості системи вищої освіти дає поштовх до реалізації стратегій удосконалення якості професійної підготовки студентів, формування у них необхідних компетентностей, необхідних для повноцінного виконання професійних обов'язків в умовах міжнародної мобільності та інтеграції.

Саме тому актуальність пропонованого дослідження зумовлена потребою поєднання сучасних технічних можливостей $з$ вимогами суспільства щодо компетентностей майбутніх фахівців інженерного профілю, необхідністю забезпечення процесу організації навчання студентів-бакалаврів інженерних спеціальностей за допомогою платформи Moodle і недостатньою розробленістю означеної проблеми в педагогічній науці, окрім того, високим освітнім та дидактичним потенціалом дистанційної платформи Moodle та недостатнім його використанням у процесі навчання бакалаврів інженерних спеціальностей під час формування правової компетентності.

Аналіз останніх досліджень і публікацій. Теоретичну базу дослідження склали фундаментальні праці дослідників, що розкривають психологопедагогічні та методичні аспекти обраної проблеми: теорія навчальної діяльності (О. Овчарук [5]), застосування компетентнісного підходу у навчанні, сучасні інструменти освіти (Л. Висоцький [3]). Увага науковців зосереджувалася на визначенні та шляхах формування правової компетентності студентів різних профілів, під якою розуміють інтегративну якість особистості, що має вияв у низці сформованих знань, умінь та навичок правової галузі (Н. Бакланова [1]). Дослідники зверталися до виокремлення складових правової компетентності, акцентували увагу на організації освітнього процесу щодо формування цих складових, наголошували на необхідності та значимості застосування комп'ютерних технологій під час занять 3 правових дисциплін (О. Ватунський [2]). Окремі роботи присвячено проблемам підвищення ефективності навчального процесу за допомогою інформаційних комп'ютерних технологій, організації дистанційного навчання за допомогою електронних систем (О. Кирколуп [4], J. Lima [7]).

Проте, незважаючи на численні наукові розвідки з різних аспектів означеної проблеми, слід зауважити, що потенціал електронної навчальної платформи Moodle під час формування правової компетентності бакалаврів інженерних спеціальностей у процесі фахової підготовки досі не було розкрито.

Мета статті - висвітлення можливостей використання електронної навчальної платформи Moodle в процесі формування правової компетентності бакалаврів інженерних спеціальностей під час фахової підготовки у закладах вищої освіти. Завданнями дослідження $\epsilon$ визначення поняття правової компетентності бакалавра інженерних спеціальностей, виявлення шляхів реалізації процесу формування правової компетентності майбутніх інженерів за допомогою навчальної платформи Moodle.

Виклад основного матеріалу. Конкурентоспроможність сучасного фахівця залежить від сформованості його професійної компетентності, яка, зі свого боку свою чергу містить низку складових у своїй структурі. При цьому комплекс необхідних компетентностей може варіюватися відповідно до профілю навчання, спеціальності та обумовлюватися різними зовнішніми чинниками - соціальноекономічними змінами у суспільстві, науковотехнічним прогресом, попитом на фахівців певних галузей тощо. Саме тому завданням компетентнісного підходу є спрямування навчальної діяльності на формування необхідних компетентностей, якими має володіти студент, установлення зав'язків між ними.

Процес набуття правової компетентності у бакалаврів інженерних спеціальностей базується на формуванні трьох її компонентів: когнітивного, емоційно-вольового та діяльнісного. Когнітивний компонент відповідає за володіння знаннями нормативної бази - законів, актів, положень; 


\section{ВИКОРИСТАННЯ ЕЛЕКТРОННОЇ НАВЧАЛЬНОӤ ПЛАТФОРМИ МООDЦЕ ЯК ЕФЕКТИВНИЙ СПОСІБ ФОРМУВАННЯ ПРАВОВОЇ КОМПЕТЕНТНОСТІ БАКАЛАВРІВ ІНЖЕНЕРНИХ СПЕЦІАЛЬНОСТЕЙ У ПРОЦЕСІ ФАХОВОӤ ПДГОТОВКИ}

уміння працювати з правовою інформацією та нормативно-правовими актами, розуміння власних і суспільних прав та обов'язків. Емоційновольовий компонент передбачає розуміння власного правового статусу, переконання у значущості законів та інших нормативно-правових документів. Діяльнісний компонент базується на правовій поведінці та правовій активності дотриманні чи порушенні законів й правил, урегулюванні конфліктів тощо.

Аналізуючи стандарти підготовки фахівців інженерного профілю [6], можна виокремити перелік обов'язкових складових правової компетентності, які має опанувати майбутній інженер під час навчання. Серед них такі: здатність використовувати основи правових знань у різних сферах діяльності, професійний зокрема; здатність коректно і зважено використовувати нормативні документи в своїй професійній діяльності; здатність володіти навичками роботи 3 нормативно-технічною документацією; готовність забезпечувати виробничу і трудову дисципліну на підприємстві відповідно до встановлених норм та правил; готовність контролювати виконання правил техніки безпеки, виробничої санітарії, пожежної безпеки та норм охорони праці; здатність розробляти й вести проєктну і технічну документацію професійної сфери: проєктно-конструкторські проєкти, біотехнічні системи тощо, здатність до проведення та виконання робіт відповідно до вимог технічної документації; готовність здійснювати контроль за виконанням робіт відповідно до вимог технічної документації; здатність брати участь у розробці (на основі стандартів та іншої нормативної документації) проєктної та робочої технічної документації в галузі процесів виробництва; готовність використовувати організаційно-правові основи управлінської та підприємницької діяльності; здатність складання та ведення технічної документації; забезпечення нормативних умов праці співробітників [6].

Отже, бачимо, що правова комптетентність фахівців інженерних спеціальностей значною мірою полягає у здатності застосовувати набуті теоретичні правові знання та вміння у різних сферах своєї професійної діяльності, зокрема у веденні нормативно-правової документації, в організації роботи відповідно до вимог тощо. Саме тому під час набуття майбутніми інженерами професійної компетентності, слід зосереджувати увагу і на цю іï складову. Проте заклади вищої освіти неюридичного спрямування зазвичай стикаються 3 проблемою недостатньої кількості годин, відведених на вивчення правових дисциплін, відсутність належної мотивації студентів, великий обсяг матеріалу. Звідси виникає необхідність пошуку альтернативних шляхів презентації необхідного матеріалу, частина 3 якого може вивчатися студентами у самостійному режимі. Отже, в межах викладання правових дисциплін застосування можливостей електронних ресурсів уважається особливо доречним.

Однією з найпопулярніших відкритих систем, на базі яких можна створити навчальні заняття, $€$ Moodle - система управління навчанням, орієнтована передовсім на якісну організацію взаємодії між викладачем та студентами, організацію дистанційної форми роботи.

Moodle - (Modular Object-Oriented Dynamic Learning Environment) - динамічне середовище навчання, вибудоване на основі модульних об'єктів. Це безкоштовне програмне забезпечення для підтримки процесу навчання або викладання. Moodle - сучасна веб-система управління навчанням, за допомогою якої користувачі можуть створювати власні онлайн-кабінети, створювати та презентувати навчальні матеріали, готувати інтерактивні завдання, брати участь у форумах, розробляти вікі-сайти, користуватися системою тестів.

Для студентів це середовище сприяє обміну знаннями через організацію взаємодії з усіма учасниками процесу, що беруть участь у процесі навчання. Робота 3 таким віртуальним навчальним середовищем грунтується на теорії конструктивізму, коли студент має автономію у набутті та засвоєнні необхідних знань.

Дистанційна платформа Moodle дає змогу організовувати декілька можливих режимів роботи студентів під час виконання різних видів навчальної діяльності: проведення замість звичайних лекцій вебінарів $з$ презентаціями, урізноманітнення аудиторних практичних занять мультимедійним супроводом, поєднання формального спілкування у діаді “студентвикладач” з неформальним (у режимі чатів), переорієнтація звичайних консультацій в режим онлайн, збагачення контрольних заходів елементами тестування тощо.

Таким чином, за браком часу на вивчення правових дисциплін окремо, частина тем або повністю курс може бути винесений на платформу для самостійного опанування студентами. Наприклад, доцільним вбачається розробка курсу “Основи правої грамотності інженера”, метою якого може бути ознайомлення 3 правовим аспектом спеціальності та формуванні складників правової компетентності відповідно до вимог освітніх стандартів. 


\section{ВИКОРИСТАННЯ ЕЛЕКТРОННОЇ НАВЧАЛЬНОЇ ПЛАТФОРМИМООDLЕ ЯК ЕФЕКТИВНИЙ СПОСІБ ФОРМУВАННЯ ПРАВОВОЇ КОМПЕТЕНТНОСТІ БАКАЛАВРІВ ІНЖЕНЕРНИХ СПЕЦАЛЬНОСТЕЙ У ПРОЦЕСІ ФАХОВОӤ ПДГОТОВКИ}

Курси 3 правових дисциплін, розроблені платформі Moodle, мають такі елементи: модульну структуру, внутрішні та зовнішні гіпертекстові посилання, інтерактивну складову, розгалужену систему контрольних завдань, прозорі умови оцінювання, гнучкість та доступність під час виконання завдань. Після розробки структури навчально-методичного комплексу визначається методика оцінки блоків та модулів курсу, виокремлюються складові елементи підсумкової оцінки за курс, визначаються критерії оцінювання.

Основні компоненти курсів 3 правових дисциплін характеризуються таким контентом: блоки і модулі, які містять інформаційні та навчальні презентації, інтерактивні вправи й завдання, складені з використанням аудіо та відеоматеріалів, тестові завдання, посилань на інтернет-джерела. При проектування навчального курсу “Основи правої грамотності інженера" доцільно застосувати набір таких елементів: “рекомендації щодо виконання", “глосарій”, “завдання”, “тест”, “форум”, “проект”.

Інструментарій Moodle дає можливість розміщувати в модулях розроблених дистанційних курсів текстову, графічну, аудіо- та відеоінформацію, різноманітні тестові завдання, опитувальники, анкети.

Спілкування між учасниками проєкту може організовуватися декількома способами: традиційним - за допомогою електронної пошти або форумів, та за допомогою вебінарів різновидів онлайн-тренінгів, під час яких викладач та студенти спілкуються у текстових, аудіо- або відеочатах. Тема розмови заняття ілюструється слайдами або роботою з віртуальною електронною дошкою. Зазвичай вебінари можуть архівуватися, що $є$ суттєвою перевагою, оскільки можуть бути у вільному доступі у будь-який час.

Первинне ознайомлення 3 теоретичним матеріалом зазвичай може проводитися у форматі презентації, що передбачає наочніть та збалансованість викладу матеріалу. Студент реєструється на курс, знайомиться 3 рекомендаціями щодо його виконання і починає працювати відповідно до календарно-тематичного плану дисципліни. Паралельно з опануванням теоретичного матеріалу занять відбувається знайомство 3 необхідним понятійним апаратом завдяки глосарію курсу. Наступний етап проходження й виконання завдань у запланованих практичних заняттях. Обов'язковий елемент кожного блоку - тестові завдання для контролю знань. Контролюючі матеріали вводяться додатковим розділом 3 назвою “Діагностичний модуль”. Завдання можуть бути як простими, тестовими, так і творчими - написання есе, створення презентацій тощо. Результати тестової перевірки, а також виконання усіх завдань практичних занять зберігаються у картці студента. Після закінчення кожного модуля студент виконує підсумкове тестування. Після проходження курсу студент отримує допуск до підсумкової атестації з дисципліни відповідно до кількості набраних балів.

Отже, перевагами платформи Moodle під час викладання правових дисциплін в інженерних закладах освіти $\epsilon$, можливість використання і поєднання різноманітних ресурсів та форм навчання, організація самостійної роботи вивчення тем курсу за допомогою закладених у системі теоретичних та методичних матеріалів, здійснення об’єктивного контролю знань.

Висновки. Застосування дистанційної платформи Moodle у процесі фахової підготовки бакалаврів інжирних спеціальностей під час опанування правових дисциплін підвищуватиме мотивацію студентів, забезпечуватиме різноманітність та оригінальність презентації матеріалу, сприятиме розвитку навичок самостійної і пошукової роботи студентів, а також їхніх творчих здібностей. Означена система відкриває перед викладачем інструментарій для інтерактивного забезпечення освітнього процесу, подання навчального матеріалу у зручній та цікавій формі, організації індивідуальної та групової роботи студентів під час опанування необхідних дисциплін. Проте слід пам'ятати про складнощі, серед яких імовірна розрізненість або нецікава подача матеріалу, надмірний обсяг інформації, невдала адаптованість певних видів завдань, недостатне забезпечення контрольними вимірювальними матеріалами.

\section{ЛІТЕРАТУРА}

1. Бакланова Н.М. Формування правової компетентності майбутніх учителів. Освітологічний дискурс. 2016. №2(14). С. 115-124.

2. Ватунский А. А. Платформа LMS Moodle как эффективное средство организации информационного образовательного пространства для студентов колледжа. Педагогический журнал. 2020. Т. 10. №1. С. 13-21.

3. Высоцкий Л.А. Формирование правовой компетентности студентов колледжа на основе интегративно-модульных технологий в обучении. Человек и образование. 2011. №4(29). С. 105109.

4. Кирколуп О. В. Использование платформы Moodle как формы контроля при обучении 
ВИКОРИСТАННЯ ЕЛЕКТРОННОЇ НАВЧАЛЬНОЇ ПЛАТФОРМИМООDLЕ

ЯК ЕФЕКТИВНИЙ СПОСІБ ФОРМУВАННЯ ПРАВОВОЇ КОМПЕТЕНТНОСТІ БАКАЛАВРІВ ІНЖЕНЕРНИХ СПЕЦАЛЬНОСТЕЙУ ПРОЦЕСІ ФАХОВОЇ ПДГОТОВКИ

французскому языку в магистратуре. Педагогический опыт: теория, методика, практика. 2015. Т.1 C. $178-180$.

5. Овчарук О. В. Компетентнісний підхід в освіті: Загальноєвропейські підходи. Інформаиійні технології $і$ засоби навчання. 2009. №5. С. 114.

6. Стандарт вищої освіти України: перший (бакалаврський) рівень, галузь знань 12 Інформаційні технології, спеціальність 123 Комп'ютерна інженерія. URL: https://mon.gov.ua/ s tor a g e/a p p/media/vish cha-osvita/ zatverdzeni\%20standarty/2019/05/28/123kompyuter.inzhener.bakalavr-1.pdf (дата звернення: 20.12.2021).

7. Lima J. M. Plateforme Moodle: Education par la mŭdiation technologique. Revista Cientrfica Multidisciplinar Nbcleo do Conhecimento. 2021.Vol. 07. P.17-37.

\section{REFERENCES}

1. Baklanova, N. M. (2016). Formuvannia pravovoi kompetentnosti maibutnikh uchyteliv [Formation of legal competence of future teachers]. Educational discourse, no.2(14), pp.115-124. [in Ukrainian].

2. Vatunskyi, A. A. (2020). Platforma LMS Moodle kak effektyvnoe sredstvo orhanyzatsyy informatsyonnoho obrazovatelnoho prostranstva dlia studentov kolledzha [LMS Moodle platform as an effective means of organizing information educational space for college students]. Pedagogical journal, vol. 10, pp.13-21. [in Russian].
3. Vysotskyi, L.A. (2011). Formyrovanye pravovoi kompetentnosty studentov kolledzha na osnove yntehratyvno-modulnykh tekhnolohyi obuchenyia [Formation of legal competence of college students on the basis of integrative-modular technologies in teaching]. Human and education, no. 4(29), pp.105109. [in Russian].

4. Kyrkolup, O. V. (2015). Ispolzovanye platformi Moodle kak formy kontrolia pry obuchenyy frantsuzskomu yaziku v mahystrature [Using the Moodle Platform as a Form of Control in Teaching French in Master's Degree]. Pedagogical experience: theory, methodology, practice, vol.1, pp.178-180. [in Russian].

5. Ovcharuk, O.V. (2009). Kompetentnisnyi pidkhid v osviti: Zahalnoievropeiski pidkhody. [Competence approach in education: Pan-European approaches]. Information technologies and teaching aids, no.5, pp.1-14. [in Ukrainian].

6. Standart vyshchoi osvity Ukrainy: pershyi (bakalavrskyi) riven, haluz znan 12 - Informatsiini tekhnolohii, spetsialnist 123 - Kompiuterna inzheneriia (2018). [Standard of high education in Ukraine: first (bachelor's) level, knowledge 12 - Information technology, specialty 123 - Computer engineering]. Available at:https://mon.gov.ua/storage/app/media/ vishcha-osvita/zatverdzeni\%20standarty/2019/05/28/ 123-kompyuter.inzhener.bakalavr-1.pdf (Accessed 20 Dec.2021). [in Ukrainian].

7. Lima, J. M. (2021). Plateforme Moodle: Education par la médiation technologique. Revista Cientifica Multidisciplinar Núcleo do Conhecimento, 07, 17-37 [in Spanish]

Стаття надійшла до редакції 24.12.2021

\section{G58089

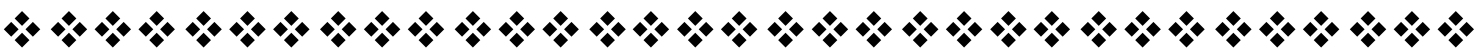

"Розумна людина завжди повинна пам'ятати про те, що, будучи нащадқом минулого, вона, одночасно, є батьком майбутнъого".

Терберт Спенсер

англійський ббілособб $i$ сойіолог

"Чим иіннішим видається людині результат ї̈ дї̈, тим з більшою ймовірністю вона повинна відтворити цюю дію”.

Dжордж Хоманс американський соиіолог

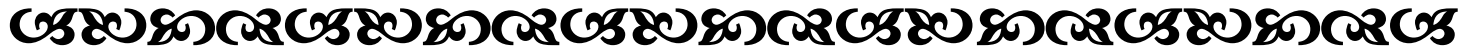

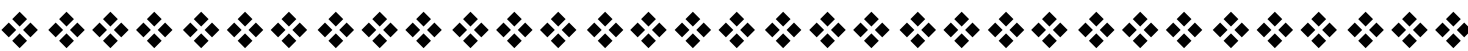

